\title{
IDENTIFIKASI BAKTERI RESISTEN MERKURI DALAM URINE, FESES, DAN KARANG GIGI PADA INDIVIDU DI DAERAH PESISIR PANTAI DESA PULISAN KECAMATAN LIKUPANG TIMUR KABUPATEN MINAHASA UTARA
}

\author{
${ }^{1}$ Devianitta Sarapi \\ ${ }^{2}$ Fatimawali \\ ${ }^{2}$ Fona Budiarso

\begin{abstract}
${ }^{1}$ Kandidat Skripsi Fakultas Kedokteran Universitas Sam ratulangi Manado
${ }^{2}$ Bagian Kimia Fakultas Kedokteran Universitas Sam Ratulangi Manado

Email: devianitta91@gmail.com
\end{abstract}

\begin{abstract}
Mercury is a metal that is very harmful for health human and the environment if not properly mercury polluted sea water can be exposed to humans especially those living in coastal areas with high consumption of marine products. Mercury pollution in the ocean triggered a mercury-resistant bacteria therefore researchers are interested in finding out if the bacteria are resistant to mercury in urine, feces, and tartar. Research design is fashion descriptive explorative. Samples taken in this study is urine, feces, and tartar on individuals who have settled more than 30 years in the rural coastal districts Pulisan, Likupang eastern district north Minahasa regency then tested in morphology, physiology and biochemistry at the FMIPA Sam Ratulangi University Sam Ratulangi biotechnology lab. Result of the study showed the presence of mercury-resistant bacteria in samples taken were found proved by mercury resistant bacteria 4 of 6 isolates that survive up to $40 \mathrm{ppm}$ and $20 \mathrm{ppm}$ in $\mathrm{HgCl}_{2}$ on Phenyl mercury is Bacillus sp, E.coli, Streptococcus sp, and Staphylococcus sp.
\end{abstract}

Keywords: Mercury, mercury resistant bacteria.

\begin{abstract}
Abstrak: Merkuri merupakan logam yang sangat berbahaya bagi kesehatan manusia dan lingkungan, jika tidak diolah dengan baik. Merkuri tercemar pada air laut dapat terpapar pada manusia terlebih yang tinggal didaerah pesisir pantai dengan konsumsi hasil laut yang tinggi. Adanya pencemaran merkuri di laut memicu munculnya bakteri yang resisten terhadap merkuri. Oleh karena itu peneliti tertarik untuk mengetahui adakah bakteri yang resisten terhadap merkuri dalam urine, feses, dan karang gigi. Desain penelitian adalah metode deskriptif eksploratif. Sampel yang diambil dalam penelitian ini adalah urine, feses, dan karang gigi pada individu yang telah menetap lebih dari 30 tahun di daerah pesisir pantai Desa Pulisan Kecamatan Likupang Timur Kabupaten Minahasa Utara. Kemudian diuji secara morfologi, fisiologi, dan biokimia dilaboratorium bioteknologi FMIPA Universitas Sam Ratulangi. Hasil penelitian menunjukan adanya bakteri resisten merkuri pada sampel yang diambil. Terbukti dengan ditemukan 4 bakteri resisten merkuri dari 6 isolat yang bertahan sampai 40 ppm pada $\mathrm{HgCl}_{2}$ dan 20 ppm pada Fenil merkuri, yaitu: Bacillus sp, E.coli, Streptococcus sp, dan Staphylococcus sp.
\end{abstract}

Kata Kunci: Merkuri, bakteri resisten merkuri.

Merkuri adalah zat yang berbahaya bersifat toksik. Pelepasan logam berat dalam lingkungan membahayakan ekosistem dan menyebabkan bahaya serius bagi kesehatan manusia. Merkuri masuk dalam tubuh manusia melalui makanan, minuman, udara pernafasan dan terpapar langsung pada kulit. $^{1,2}$

Merkuri sebagai sumber pencemar dapat berupa logam, senyawa organik dan 
anorganik. Senyawa organik adalah senyawa yang paling berbahaya khususnya metil merkuri dan fenil merkuri. Metil merkuri dikenal sebagai pencemar air dan endapan di laut melalui proses sedimentasi Hg. ${ }^{3}$

Konsentrasi merkuri yang tinggi di biosfir akan terakumulasi dalam lingkungan yang menyebabkan keracunan pada berbagai organism, terutama pada manusia dan hewan, sehingga dapat berdampak pada manusia berupa gangguan fisiologis, gangguan sistem saraf, gangguan pertumbuhan dan gangguan terhadap ginjal. Tapi dalam tubuh manusia terdapat bakteri yang resisten terhadap merkuri. Walaupun terpapar secara langsung dengan waktu yang lama oleh merkuri yang terdapat pada hasil laut yang sering dikonsumsi oleh manusia seperti ikan, tetapi tidak berdampak negatif atau menimbulkan gejala-gejala keracunan merkuri. $^{4,5}$

\section{METODE PENELITIAN}

Penelitian ini bersifat deskriptif eksploratif. penelitian ini dilakukan di Laboratorium Biologi Fakultas MIPA Universitas Sam Ratulangi Manado sejak November 2013 sampai Januari 2014.

Penelitian ini dilakukan dengan beberapa tahap, yaitu tahan isolasi bakteri resisten merkuri dimana bertujuan untuk mengisolasi bakteri-baktri yang ada pada sampel urine, feses, dan karang gigi. Cara kerjanya, koloni ditumbuhkan pada media Nutrient Agar yang sudah mengandung merkuri setelah perhitungan total koloni, kemudian dipindahkan ke media agar miring dengan menggunakan jarum ose sebagai kultur sediaan (isolat) dan selanjutnya disimpan pada suhu $40^{\circ} \mathrm{C}$. setelah itu dilakukan seleksi kultu bakteri, seleksi ini dilakukan dengan cara inokulasi kultur bakteri sampel dalam media seleksi padat yang mengandung $\mathrm{HgCl}_{2}$ dengan konsentrasi 10, 20, 40 ppm dan fwnil merkuri dengan konsentrasi 5, 10, 20 ppm kemudian diinkubasi pada temperature $37^{\circ} \mathrm{C}$ selama 24 jam. Selanjutnya diamati jumlah koloni yang tumbuh.
Selanjutnya dilakukan uji morfologi dengan pewarnaan Gram. Tahap-tahap dalam penentuan Gram bakteri sebagai berikut, kaca objek di bersihkan dengan kapas yang telah diberi alcohol lalu diberi label. Bikan bakteri pada Nutrient Agar miring diambil dengan menggunakan jarum ose, kemudian ditotol pada bagian tengah kaca objek sampai merata. Preparat selanjutnya difiksasi di atas lampu spritus lalu diberikan larutan Kristal Violet dan dibiarkan selama 1 menit, lalu dicuci dengan aquades dan dikeringkan dengan tissue. Kemudian tetes dengan larutan Lugol, biarkan selama 30 detik dan bilas dengan alcohol lalu kembali dicuci dengan aquades dan dikeringkan. Kemudian diberi larutan Sefranin, biarkan 30 detik dan kembali dicuci dengan aquades dan keringkan. Preparat yang telah diberi minyak emerasi diperiksa pada mikroskop dengan pembesaran 1000 kali. Hasil positif jika bewarna ungu dan negatif bewarna merah muda.

Prosedur untuk uji fisiologi yaitu, siapkan media Motility Test Medium dan dimasukkan ke dalam tabung yang diberi label sesuai kode biakan bakteri yang digunakan sebanyak $5 \mathrm{ml}$ kemudian media disterilkan pada suhu $121^{\circ} \mathrm{C}$ selama 15 menit dan setelah itu didinginkan. Setelah media sudah dingin, diinokulasikan dengan tusukkan jarum ose sampai ke dasar media dan diinkubasi pada suhu $37^{\circ} \mathrm{C}$ selama 2448 jam. Lakukan pengamatan setelah masa inkubasi. Hasil positif bila terjadi pertumbuhan melebar dari bekas tusukkan jarum ose.

Uji biokimia dilakukan setelah uji morfologi dan fisiologi. Uji ini terdiri dari uji indol, uji $\mathrm{H}_{2} \mathrm{~S}$, uji sitrat, uji katalase, uji fermentasi karbohidrat, dan uji lysine dekarboksilase.cara kerja uji indol sebagai berikut, isolat diinokulasikan ke tabung semi padat (Motility Test Medium) dengan koloni biakkan yang berasal dari masing-masing agar miring dengan cara ditusukkan jarum sedalam ${ }^{3 / 4}$ bagian. Diinkubasi pada suhu $35^{\circ} \mathrm{C}$ selama 24 jam, dengan menambahkan 0,2-0,3 $\mathrm{ml}$ reagen covac's. Hasil indol positif apabila kultur bewarna merah saat 
ditambahkan reagen. Prosedur kerja $\mathrm{H}_{2} \mathrm{~S}$ sebagai berikut disiapkan media Triple Sugar Iron (TSI), inokulasi bakteri dengan cara digores lalu ditusuk pada media. Diinkubasi pada suhu $37^{\circ} \mathrm{C}$ selama 24 jam. Hasil positif bila terbentuk endapan warna hitam pada dasar media berarti bakteri mampu membentuk $\mathrm{H}_{2} \mathrm{~S}$. prosedur kerja uji sitrat, disiapkan media Simmon 's Citrate Agar dan diberi label sesuai kode biakan bakteri, dimana tabung berada pada posisi miring. Inokulasi secara aseptik biakan pada media dengan cara permukaan digores. Kemudian diinkubasi pada suhu $37^{\circ} \mathrm{C}$ selama 24-48 jam kemudian dilakukan pengamatan. Hasil positif bila terjadi perubahan warna media dari hijau menjadi biru dan negatif bila tidak terjdi perubahan warna. Prosedur kerja uji katalase, dibuat media Natrium Broth kemudian dimasukkan ke dalam tabung reaksi sebanyak $5 \mathrm{ml}$ kemudian kultu sediaan diinokulasi ke dalam tabung reaksi yang berisi Natrium Broth. Selanjutnya, diinkubasi pada suhu $37^{0} \mathrm{C}$ selama $24-48$ jam. Kemudian ditambahkan 3-4 tetes 3\% hydrogen peroksida ke dalam kultur biakan. Hasil positif bila terjadi gelembung udara. Prosedur kerja uji fermentasi karbohidrat, dibuat media Triple Sugar Iron Agar (TSIA) kemudian dimasukkan ke dalam tabung Hach sebanyak $6 \mathrm{ml}$ setelah itu media disterilkan pada suhu $121^{\circ} \mathrm{C}$ selama 15 menit, lalu diletakkan pada posisi miring sampai dingin. Bila sudah dingin, secara asepik setiap isolate bakteri diinokulasi dengan jarum inokulasi lurus dengan cara ditusuk pada bagian tengah sampai kedalaman ${ }^{3 / 4}$ bagian dari permukaan media, setelah itu digores pada bagian miring media, kemudian inkubasi selama 24 jam pada suhu $37^{\circ} \mathrm{C}$. kemudian dipriksa apakah ada fermentasi karnohidrat dengan melihat pembentukan asam dan gas.pembentukan asam terlihat sebagai perubahan warna substrat karbohidrat dari warna merah menjadi kuning. Pembentukan gas terlihat dalam tabung Durham. Jika mikroorganisme hanya dapat memfermentasikan glukosa, maka bagian butt media akan bewarna kuning dan bagian slantnya akan bewarna merah. Bila mikroorganisme dapat memfermentasikan laktosa dan sukrosa atau keduanya, maka bagian slant dan butt media akan bewarna kuning serta bagian butt mdia kadangkala terpecah akibat pembentukan $\mathrm{H}_{2}$ dan $\mathrm{CO}_{2}$. Prosedur kerja uji lysine dekarboksilas, disiapkan media Lysin Iron Agar lalu sebanyak $6 \mathrm{ml}$ media dimasukkan ke dalam tabung Hach. Media disterilkan dengan autoclave pada suhu $121^{\circ} \mathrm{C}$ selama 15 menit. Setelah disterilkan, media dibuat menjadi media miring. Kemudian bakteri diinokulasikan dengan cara ditusukkan dan digoreskan pada media LIA miring. Diinkubasi pada suhu $37^{\circ} \mathrm{C}$ selama 24 jam. Hasil positif bila terjadi perubahan warna pada media menjadi lembayung, sedangkan negatif ditandai dengan warna kuning pada media.

Setelah dilakukan uji Morfologi, Fisiologi dan uji Biokimia, maka data dikumpulkan dalam table kemudian hasil ini dibandingkan dengan petunjuk yang terdapat dalam Burgey's Manual Determinative of Bacteriology.

\section{HASIL DAN BAHASAN}

Hasil dari isolasi bakteri resisten merkuri didapatkan pada konsentrasi $\mathrm{HgCl}_{2}$ 10 ppm dan 20 ppm bakteri tumbuh dengan baik pada semua isolat. Pada konsentrasi 40 ppm masih terdapat pertumbuhan bakteri tetapi hanya sedikit bakteri yang tumbuh pada semua isolat. Pada konsentrasi Fenil merkuri 5 ppm dan 10 ppm bakteri tumbuh dengan baik pada semua isolat. Pada konsentrasi Fenil merkuri 20 ppm pertumbuhan bakteri yang terdapat pada semua isolat sudah sedikit. Yang diambil bakteri yang tumbuh pada konsentrasi $\mathrm{HgCl}_{2} 40$ ppm dan Fenil merkuri pada konsentrasi 20 ppm.

Identifikasi d.U 40 menunjukkan gambaran basil Gram negatif yang motil dengan hasil uji indol negatif, katalase positif, fermentasi laktosa dan sukrosa, uji sitrat dan lysin positif, serta uji $\mathrm{H}_{2} \mathrm{~S}$ negatif. Dengan melihat karakteristik dari hasil pengujian, bakteri ini mirip dengan Bacillus $s p$. Bacillus sp. bersifat aerobik tapi juga 
dapat bersifat fakultatif anaerob. Metabolisme dengan fermentasi dan respirasi. Biasanya banyak terdapat dipermukaan tanah, debu dan susu.

Identifikasi d.F 40 menunjukkan kokus Gram negatif yang motil dengan hasil uji indol negatif, katalase positif, fermentasi glukosa dan gas, uji sitrat dan lysin positif, serta uji $\mathrm{H}_{2} \mathrm{~S}$ negatif. Dari hasil uji yang dilakukan maka disimpulkan bakteri adalah bakteri E.coli. E.coli merupakan bakteri yang resisten terhadap panas, media tumbuh optimum yaitu $30-37^{\circ} \mathrm{C}$.

Identifikasi d.KG 40 menunjukkan gambaran kokus Gram negatif yang motil, indol negatif, katalase positif, memfermentasikan glukosa, uji sitrat dan lysin positif serta $\mathrm{H}_{2} \mathrm{~S}$ negatif. Disimpulkan hasil uji yang dilakukan merupakan bakteri Streptococcus sp. Bakteri ini dapat menghasilkan asam laktat, terdapat di rongga mulut, karena bakteri ini juga merupakan flora normal yang terdapat dimulut. Bakteri ini merupakan bakteri penyebab awal proses karies gigi.

Identifikasi d.KG 20 menunjukan kokus Gram negatif, tidak motil, dengan uji indol positif, katalase positif, memfermentasikan glukosa, uji sitrat dan lysin positif serta $\mathrm{H}_{2} \mathrm{~S}$ negatif. Dengan bakteri Staphylococcus sp.

Identifikasi d.F 20 menunjukkan basil Gram negatif yang motil, indol positif, katalase positif, memfermentasikan laktosa, sukrosa dan gas, uji sitrat dan lysin positif serta $\mathrm{H}_{2} \mathrm{~S}$ negatif. Hasil pengujian bakteri, bakteri ini mirip dengan Bacillus sp.

Identifikasi d.U 20 menunjukkan kokus Gram negatif yang motil, indol negatif, katalase positif, memfermentasikan glukosa, sitrat dan lysin positif serta $\mathrm{H}_{2} \mathrm{~S}$ negatif. Bakteri yang didapat dari uji ini mirip dengan bakteri E.coli.

Dari hasil penelitian ini bakteri yang ditemukan dalam urine, feses, dan karang gigi pada individu di daerah pesisir pantai Desa Pulisan terdapat perbedaan dengan jenis bakteri yang diisolasi dari urine pasien Tumpatan Amalgam Poli Gigi Puskesmas Bahu (Gagola R, 2010). Pada penelitian tersebut ditemukan bakteri resisten merkuri yaitu, Alcaligenes, Neisseria, Planococcus, Marinococcus, Streptococcus dan Morococcus.

Dari kedua hasil penelitian ini, maka dapat disimpulkan bahwa setiap bakteri memiliki tingkat resistensi yang berbeda. Hal ini disebabkan karena adanya perbedaan gen yang terdapat pada plasmid dan kromosom. Faktor lingkungan juga turut mempengaruhi tingkat resistensi merkuri.

\section{SIMPULAN DAN SARAN}

Dari hasil penelitian yang didapatkan, dapat disimpulkan:

1. Melalui identifikasi bakteri resisten merkuri pada urine, feses, dan karang gigi pada individu yang tinggal di daerah pesisir pantai Desa Pulisan Kecamatan Likupang Timur Kabupaten Minahasa Utara maka diperoleh 6 isolat yang resisten merkuri melalui uji morfologi, fisiologi dan uji biokimia didapatkan 4 genus bakteri resisten merkuri yaitu, Bacillus sp, E.coli, Streptococcus sp, dan Staphylococcus sp.

2. Dari uji tingkat resistensi bakteri terhadap merkuri didapatkan untuk $\mathrm{HgCl}_{2}$ bakteri mampu bertahan hingga 40 ppm dan Fenil merkuri bakteri hanya mampu bertahan hingga 20 ppm.

Untuk lebih jauh mengetahui peranperan bakteri resisten merkuri, maka sebaiknya dilakukan penelitian lebih lanjut dengan menggunakan metode yang lainnya, yaitu biologi molekuler serta menambah ujiuji biokimia lainnya selain uji-uji yang dilakukan peneliti.

\section{UCAPAN TERIMA KASIH}

Ucapan terima kasih kepada DR. Dra. Fatimawali, MSi, Apt dan dr. Fona Budiarso, MSi serta semua pihak yang secara langsung maupun tidak langsung telah menumbuhkan ide tau gagasan dalam pemikiran penulis sehingga dapat menyelesaikan artikel ini. 
480 Jurnal e-Biomedik (eBM), Volume 2, Nomor 2, Juli 2014, hlm. 476-480

\section{DAFTAR PUSTAKA}

1. Aaltje E M, Billy J K. Studi Populasi Bakteri Resisten Merkuri Di Daerah Aliran Sungai Tondano, Kelurahan Ketang Baru, Manado. Available from: Journal.unsrat.ac.id/index.php/JIS/article/do wnload/36/32. 20 September 2013

2. Fatimawali, Fatmawati B, Irawan Y. Isolasi Dan Identifikasi Bakteri Resisten Merkuri Dari Muara Sungai Sario Yang Dapat Digunakan Untuk Detoksifikasi Limbah Merkuri. Available from: Ejournal.unsrat.ac.id/index.php/JIS/article/d ownload/220/171. 20 September 2013
3. Yuniaty, S.2011.Identifikasi Isolat Bakteri Resisten Merkuri pada Media Kultur awal yang mengandung merkuri dikelurahan Ketang Baru, kota Manado.Karya Tulis Ilmiah Fakultas Kedokteran Universitas Sam Ratulangi. BAB 1, halmn 2

4. Merdekwati.(2013).Dampak pencemaran merkuri terhadap biota air \& kesehatan manusia.

5. Bobby J P, Desmi N S. Pendugaan Kandungan Merkuri Dan Sianida Di Daerah Aliran Sungai Buyat Minahasa. Available from:

Ejournal.unsrat.ac.id/index.php/Ekoton/artic le/download/260. 22 September 2013 